\begin{abstract}
The following study is concerned with understanding the emergence of neoliberalism in Costa Rica since the apex of the debt crisis in 1982 to present from a historical materialist analytical framework. My particular framework is concerned with the centrality of social classes and the role of state in defining and shaping class conflict and the effects of historical class conflict on the state through changes in the social relations of production and internationalization. This critical exploration will be approached not by looking solely within the confines of national borders, but rather by analyzing the emergence as a moment within the wider capitalist world market. I will argue that the emergence of neoliberalism in Costa Rica not only reflects a new form of political domination but also expresses a new form of imperialism; both of these aim to overcome recurrent barriers to progressive capital valorisation and to reconstitute American power. However, as but a historical moment, neoliberalism is open to social contestation and learning processes - that is, class struggle. A critical understanding this emergence is best approached through an analysis of the interrelated dimensions of capital, crisis, and state, which are themselves social forms and moments of the wider social relations of capitalist production.
\end{abstract}

\title{
From Economic Crisis to a 'State' of Crisis?: The Emergence of Neoliberalism in Costa Rica ${ }^{1}$
}

Macro-economic development promoted by globalization has not translated into social benefits for the people of Central America .... Out of a total population of 37 million, 12 million Central Americans are now living in conditions of misery.

Roberto Cuellar, Executive Director

Inter-American Institute of Human Rights ${ }^{2}$

[Costa Rica] is not a country of crisis. There are indeed people who are living them, but not the country.

Helio Gallardo, San José, $1993^{3}$

\section{Introduction}

At first glance, the largely Spanish-speaking democratic republic of Costa Rica, nestled between Nicaragua to the north and Panama to the south, may not be seen as integral to analyses of the dynamics of neoliberalism's emergence in crisis. What can critical scholars hope to gain from looking at a relatively small country with a population of around four million, many of whom live in and around the capital city of San José? Most mainstream analyses point out that since the end of World War II and the formal abolition of its standing army, Costa Rica has come to be one of the wealthiest countries in Central America boasting a stable and extensive welfare state into the 1980s. Costa Rica's gross domestic product (GDP) per capita currently rests around \$4200 US with per capita income growth that has surpassed all other Central American states. Relative to others in Central America, Costa Rica's income has averaged more than double that of Honduras, El Salvador, and Nicaragua, and has in the last decade overtaken Panama. Through the mid-1990s, the United Nations Development Program Human Development Index ranked Costa Rica as the most developed country in Latin America. ${ }^{4}$ If one is to be satisfied with surface analyses, then this story, popular amidst Costa Rican technocrats, elites, and international financial institutions for the celebrated success of neoliberal reform, has been told. This is not the whole story, however, and certainly not the only story when looked at from a critical lens. Rather, one sees that 
across Central and Latin America ongoing harsh economic adjustment, recurrent crisis, and stagnant to volatile socio-economic growth is the more common day to day story. The popular response to this reality has been a rash of strikes across healthcare, education, and public service related sectors that involve a rainbow of men, women, ethnicities, and socio-economic classes. What this dissent suggests is that however dominant, neoliberalism's legitimacy, or its ability to govern consensually based upon fulfilling material, class-based compromises, remains a struggling, albeit stabilizing, project. The task of critical scholars, and the point of this study, is to unveil neoliberalism as more than mere policy prescriptions and to reveal its underlying classbasis as part of the wider project of emancipation.

To this end, the following study seeks to re-interpret the post-1980s emergence of neoliberalism in Costa Rica by recognising the centrality of social classes and the role of state in defining and shaping class conflict and the effects of historical class conflict on the state through changes in the social relations of production. ${ }^{5}$ From the onset, I reject the dominant 'common sense' understandings of neoliberalism that are expressed merely as a core set of ahistorical neoclassical economic policies that are often cited as the Washington consensus. Ironically, these common sense discussions are typically framed in overly technical and narrowly economic terms, focusing uncritically on the efficiency of the market within liberal or institutionalist frameworks. ${ }^{6}$ More critical accounts exist, but they have tended to draw upon the so-called globalization thesis the idea that states are withering away under the sweeping powers of transnational actors and corporations. ${ }^{7}$ In contrast, I begin by adopting an analytical framework that emphasizes a synthesis of three interrelated dimensions, namely global capital, crisis, and state. This triad itself comprises a moment within the same wider social relations of capitalist production. ${ }^{8}$ As opposed to policy-based analyses, I suggest neoliberalism is best understood as a historical, class-based ideology that proposes all social, political, and ecological problems can be resolved through more direct free market exposure, which has become an increasingly structural aspect of capitalism. ${ }^{9}$ Drawing on this framework, I argue that the emergence of neoliberalism in Costa Rica not only reflects a new form of political domination but also expresses a new form of imperialism; both of these aim to overcome recurrent barriers to progressive capital valorisation and to reconstitute American power. ${ }^{10}$ It should be emphasized that this critical exploration will be approached not by looking solely within the confines of the national borders but rather by analyzing neoliberalism's historically specific emergence within the wider capitalist world market. ${ }^{11}$

To make this argument, I look first at Costa Rica's pre-1980s social relations of production within Central America and, second, at how the crisis of the 1980s opened a door for neoliberal reform. In the third section I present a detailed examination of the relationship between US assistance and Costa Rican social forces in the subsequent restructuring of state and associated class compromises. A brief look at efforts to privatize its national banking system serves to introduce us to the rising neoliberal financial orthodoxy. To round off this study, section four assesses Costa Rica's 'successes' within Latin America's failures to achieve substantive development over the last twenty-plus years. By way of conclusion, I place this analysis within the context of the new imperialism.

\section{Costa Rica: A Historical Overview}


The relative prosperity of Costa Rica has given rise to a number of interpretations. It is true that the class-structure of Costa Rica has developed somewhat differently than elsewhere in the region given a general absence of the larger haciendas of, for example, Mexico and Guatemala. This absence and relative wealth and stability have given rise to a widespread 'myth of exceptionalism' that has wrongly argued that Costa Rica is a harmoniously democratic state that has emerged from a particularly egalitarian colonial and post-colonial history. In contrast to this dominant 'rural democracy' or 'yeoman' thesis, however, Costa Rica was not and is not a classless society of subsistence farmers. Social stratification and class-conflict have been quite present and many of the dominant elites today can trace their lineage back to early Spanish conquistadores and associated class-privilege. The modern expression of this class cleavage became evident with the introduction of coffee production in the early $19^{\text {th }}$ century when the landed oligarchy solidified state power and labour shortages made large estates unfeasible. As a result, smallholder farming dominated production while the larger and wealthier growers dominated processing, financing, marketing, and exporting, creating a commercial and financial oligarchy. This was the historical context for a more unified power bloc in the post-WWII era and a political system that was more reliant on ideological hegemony than direct physical coercion. ${ }^{12}$

Politically, Costa Rica has come to be a generally stable constitutional democracy wherein its 1949 Constitution arose out of falling standards of living, general social unrest foreshadowed by the July 1947 popular strike "Huelga de Brazos Caídos," and the brief 1948 civil war. The civil war's most immediate cause was the annulment of that year's presidential elections - allegedly won by Otilio Ulate Blanco of the opposing Party of National Unification - by the constitutional congress still loyal to the exiting president Calderón (1944-48) and his hand-picked successor, Teodoro Picado. ${ }^{13}$ The triumphant political expression of the civil war was the newly formed National Liberation Party (PLN). A staunchly anti-communist consensus formed within the national power bloc, later led by industrial capital, which favoured the institutionalization of social conflict and technocratic solutions to overcoming barriers to progressive capital valorisation. ${ }^{14}$

The post-WWII economic model was an expression of state-led capitalist accumulation marked by extensive nationalizations (among the most significant were the private banks), expanded agro-export, and a contradictory import substitute industrialization (ISI) development model that remained consistent with Keynesian capitalism. $^{15}$ Regional trade and ISI, a development model supported by the Economic Commission for Latin America and the Caribbean (ECLAC) and the Prebisch modernization thesis, were first pursued through a series of bilateral trade agreements within Central America. ${ }^{16}$ Early attempts to minimize export dependence, however, were put aside because of European economic recovery and expanded American consumption that doubled the price of coffee from 1950-55. Thus, while earning the much-needed foreign currency for ISI diversification, the short-term boom actually deepened dependency upon US-based export earnings - a dependency that was encouraged through the Costa Rican Ministry of Agriculture and the now-nationalized banking system. ${ }^{17}$ By the late 1950s, the need to diversify agricultural export commodity (EXA) production, which had been extended to its ecological limits, became increasingly salient. Resisting such change was the politically and economically entrenched agro-export capital that in the mid-1950s still accounted for 90 percent of all export earnings. ${ }^{18}$

At the same time, Central America was experiencing declining terms of trade that led to a balance of payments crisis due to continued reliance on imports for intermediate 
goods. ${ }^{19}$ Globally, inter-regional trade had grown while competitive pressures emanated from the Far East in the form of cheaper wages, thereby putting increased pressure upon the Costa Rican government to capture and maintain emerging multinational corporations (MNCs) and their production facilities that were beginning to shift sites globally. ${ }^{20}$ In response, the Central American Common Market (CACM) was established in 1963 as a strategy to recreate capital valorisation opportunities regionally. However, this counter-strategy was merely grafted onto the pre-existing dominant export-led model in order to minimize EXA capital's political opposition to the CACM. ${ }^{21}$ This capitalist class-friendly approach gave rise to a schizophrenic state-led policy of ISI-promotion and EXA export-accommodation. ${ }^{22}$ Costa Rican technocrats, co-opted by ECLAC into adopting the model, well understood that the schizophrenic model would deepen export dependency but they proceeded in the belief that they ought not to alienate the traditional oligarchy and also in the faith that the model would reap ECLAC's professed political and social modernization. ${ }^{23}$ The result was the stillbirth of an alternative growth model. Production remained capital-intensive, biased towards consumer goods, heavily dependent on imports, and with few opportunities for backward linkages because of import preferences inherent to the system. ${ }^{24}$

Through the global decline of the late-1960s and early-1970s, the CACM industrialization benefits, shaped and financed by US President Kennedy's 'Alliance for Progress,' remained substantial and attractive - so much so that they were taken up by foreign, largely American, capital that began to acquire a dominant position within leading Costa Rican industrial branches. ${ }^{25}$ In contrast, domestic capital, cajoled by state appeasement strategies, remained by-and-large within the EXA sector. Nevertheless, within the facilitating context of the Alliance for Progress, Costa Rican industry thrived with more than one hundred new industrial companies being established between 196375 and annual profits growing by nineteen percent between 1962-73; this profitable framework was made possible by the Costa Rican government (with US assistance) via tax incentives, labour negotiations, and the centralization of infrastructure within the Central Valley. ${ }^{26}$ Industrial foreign capitals' relative power thus grew into the 1970 s through a series of fluid relationships with traditional power holders within the Costa Rican power bloc (EXA, finance, commerce) such that it was now in a position to have a much greater degree of influence upon the emerging, post-CACM development model that now was experiencing the end of the so-called 'easy' phase of ISI. ${ }^{27}$

In the 1970s, both the PLN administrations of Figueres (1970-74) and Oduber (1974-78) continued to give high priority to industrial development in attempts to decrease vulnerability to the still dominant EXA model. The 1970s oil shocks, however, kept EXA commodity prices high, especially coffee, and therefore important to overcoming rising import costs. ${ }^{28}$ This period nevertheless experienced a switch in development strategies toward establishing state-owned enterprises (SOEs) as a means of channelling finance into industry with a majority domestic-shareholding through the newly-formed state-run development corporation, Corporación Costarricense de Desarrollo (CODESA). For the first time, CODESA gave the Costa Rican state an important share of industrial output through its majority-equity shares; ${ }^{29}$ this in turn briefly shifted the balance of class forces to the side of labour and public production within the state. On the other hand, the manoeuvre shifted financial resources towards industry thereby implying cutbacks elsewhere - such as in available credits for small, campesino (peasant) farmers. By the early 1980s and in the wake of world recession, the financing of large SOEs proved an unbearable strain as Costa Rica's finances was laid bare by the effects of the 1982 debt crisis. 


\section{Neoliberalism's Opportunity in Crisis}

The 1974-75 and 1979-82 world recessions led Costa Rica, like much of Latin America, into a period of economic crisis from which its social relations of productions emerged under neoliberalism and a more aggressive export-led growth model. In 1980, Costa Rica's foreign debt reached 56.8 percent of GDP (US $\$ 2.7$ billion), an early indicator of the deteriorating terms of trade that eroded significantly from 1980-85 greatly hindering its ability to repay loans taken during the 1970 s - a situation further exacerbated by higher oil prices and interest rates. ${ }^{30}$ The 1982 debt crisis' apex also manifested in a drop in industrial production (-4.3 percent in 1981 and -7.7 percent in 1982), skyrocketing inflation, dramatic price increases (65.1 percent in 1981 and 81.8 percent in 1982), a contraction in public and private investment, rising unemployment and underemployment, a growing fiscal deficit, a drop in external commerce, and an associated strong balance of payments disequilibria - all of which led to an overall standard of living decrease for the majority of Costa Ricans. ${ }^{31}$ Significantly, external public debt, already high due to the recessions of the 1970 s and state enterprise financing, grew even more to a level of $\$ 3.825$ billion in 1984 or, in other words, to a level whose service engulfed 44 percent of the total value of exports from 1983-84. ${ }^{32}$ The overall severity of Costa Rica's experience with the 1980s crisis is testified to in part by the fact 1990 GDP levels were below 1980 levels.

The 1982 presidential election occurred at the height of the debt crisis and saw the quietly centre-left PLN Monge administration take power (1982-86). Despite its leftleaning rhetoric, significant neoliberal restructuring was initiated under Monge as deep economic reforms were initiated and a very profound relationship with the International Monetary Fund (IMF) and the United States Agency for International Development (USAID) was nurtured. Initial macroeconomic recovery began with an attempt to restore domestic and international confidence through the PLN-authored '100-Day Plan' of austerity measures that sought to regain control of the exchange rate, cut government and semi-autonomous institutions' budgets, remove price controls on basic consumer goods, and raise taxes - that is, the very conditions required by the IMF to reopen stalled negotiations and thus receive desperately needed bridging loans. ${ }^{33}$

Here, as in much of Latin America, we see Costa Rica's debt crisis as opportunity for neoliberal restructuring in crisis $^{34}$ - for just one year prior, in August of 1981, the IMF was expelled by the conservative, center-right, Carazo Unidad administration (197882). ${ }^{35}$ President Carazo argued that the unreasonable conditions demanded by the IMF were overtly harming the poor and that Costa Rica need not, by the mere fact of the IMF proposing adjustments, initiate them to the detriment of the nation. ${ }^{36}$ Now, however, the materiality of crisis and the discourse of conditionality quickly came to be used as a pretext to do what was politically impossible earlier - as Monge would later declare, 'with or without the IMF, it was indispensable that we initiated adjustment and stabilization... without this adjustment, however painful or unwelcome it has been, Costa Rica would have been overwhelmed by social turbulence'. ${ }^{37}$ Central Bank president, Dr. Carlos Manuel Castillo, was quick to reiterate the 'inevitability' of adjustment. ${ }^{38}$ To the credit of the 100-Day Plan, nonetheless, the Gross National Product (GNP), which had fallen to its lowest point of -11.5 percent in $1981-82,{ }^{39}$ began to improve while exports recovered, leading to what has been called in macroeconomic terms the milagro costarricense (Costa Rican miracle). ${ }^{40}$ In the aftermath, the institutional form of state was now judged as the source of economic crisis by the IMF and global capitalist power blocs with the 
common sense solution being 'less state, more market' - a solution, as we know, that demanded the reconfiguration of the role of state away from its direct stake in production. ${ }^{41}$ Reconfiguration thus implies a shift in the balance of class forces within the state as it becomes increasingly articulated relative to the capitalist world market.

Since crisis emerged in part as an expression of labour's productivity (but is experienced by capital as a crisis of competition), ${ }^{42}$ a more sustained assault on labour and the popular classes was endorsed domestically. The domestic consensus included the PLN Monge administration, neoliberal technocrats (American and Costa Rican), Central Bank President Carlos Manuel Castillo, and the domestic power bloc composed of commercial, industrial, agro-export, and finance capitals. ${ }^{43}$ Together, these actors exercised collective class agency to overcome crisis through strategizing and proceeding to renew progressive capital accumulation in Costa Rica as follows: (1) a generalized repression of workers' wages, rights, and unions (2) the disciplining of labour through massive layoffs and de-capitalization of industry (3) the opening up of the labour market to more competition (4) a reduction in social programs and subsidies (5) the introduction of new production methods and (6) by seeking new markets. ${ }^{44}$ As part of this renegotiation of existing class-compromises, the Monge administration assured the USA that Costa Rica would demonstrate that 'democracy and liberty' are possible in Central America despite the looming Sandinista 'threat' in Nicaragua. ${ }^{45}$ Since Monge, practically all subsequent neoliberal reforms and state restructuring have been couched in fatalistic terms by successive PLN and PUSC governments.

\section{USAID, the Parallel State, and State Restructuring}

... what we created was a cascading conditionality where we got the Costa Ricans to agree to do what the World Bank wanted, with what the IMF wanted, and with what the commercial banks wanted. And we coordinated the whole thing so that they got a loan package ... and they in turn did what was necessary to make what all of us wanted to see done, work.

US Ambassador Curtin Winsor ${ }^{46}$

[s]ome people within the administration, myself included, tried to use the multilaterals to fight within the PLN, to use the AID, to use the World Bank. Sometimes we would try to sell them some ideas so that they would not be presented as my ideas, XX's ideas, but would appear like the World Bank or AID was pushing an idea. Sometimes we were able to go through the back door to get our ideas accepted.

PLN Technocrat ${ }^{47}$

\section{Unilateral Economic Institutions and USAID}

The class-based nature of re-orienting capitalist social relations of production is wellillustrated in Costa Rica where the emergence of neoliberalism has been underwritten by massive amounts of financial resources from the Inter-American Development Bank (IDB), IMF, World Bank (WB), and especially USAID. These vanguard economic institutions (UEIs) ${ }^{48}$ helped facilitate an end to economic crisis through the wider restructuring of global social relations of capitalist production. ${ }^{49}$ In Costa Rica, the IMF and WB helped manage its re-articulation to the world market via four signed loan agreements with the IMF from 1980-90 and three structural adjustment programs (SAPs) initiated under the auspices of the World Bank in 1985, 1989, and 1995. Each of these aimed at restructuring the institutional state's role in the economy and to open Costa 
Rica to the logic of the free market. Whereas the IDB and WB loans were for large infrastructure projects (projects that now as foundations for further privatization projects and public-private partnerships), IMF loans and USAID funds were largely used for balance of payments support and debt servicing (compare Table 1 and foreign aid to Table 2 and imports/exports). ${ }^{50}$ This financial support helped ensure the continued legitimacy of capitalism and guarded against alternative modes of production taking root in Costa Rica and Central and Latin America generally (e.g., revolutionary Cuba, Nicaragua, Chile).

Table 1: Costa Rican Foreign Aid, $1980-90$ ( $\$$ US millions) $)^{51}$

\begin{tabular}{|l|l|l|l|l|l|l|l|l|l|l|l|}
\hline & $\mathbf{1 9 8 0}$ & $\mathbf{1 9 8 1}$ & $\mathbf{1 9 8 2}$ & $\mathbf{1 9 8 3}$ & $\mathbf{1 9 8 4}$ & $\mathbf{1 9 8 5}$ & $\mathbf{1 9 8 6}$ & $\mathbf{1 9 8 7}$ & $\mathbf{1 9 8 8}$ & $\mathbf{1 9 8 9}$ & $\mathbf{1 9 9 0}$ \\
\hline USAID & 14 & 13 & 50 & 212 & 168 & 207 & 157 & 181 & 102 & 115 & 75 \\
\hline WB & 30 & 29 & 0 & 25 & 0 & 84 & 0 & 26 & 100 & 95 & 4 \\
\hline IMF & 60 & 330 & 100 & 0 & 0 & 52 & 0 & 66 & 0 & 53 & 0 \\
\hline
\end{tabular}

Table 2: Costa Rican Imports and Exports (\$US millions) ${ }^{52}$

\begin{tabular}{|l|l|l|l|}
\hline $\begin{array}{l}\text { Exports of } \\
\text { goods } \\
\text { Services }\end{array}$ and & 1195.1 & 1985 & 1990 \\
\hline $\begin{array}{l}\text { Imports of } \\
\text { goods and } \\
\text { Services }\end{array}$ & 1661.4 & 1213.8 & 1963.2 \\
\hline $\begin{array}{l}\text { Current account } \\
\text { balance }\end{array}$ & -663.9 & -291.1 & 2346.4 \\
\hline
\end{tabular}

Of these UEls, perhaps the most important in Costa Rica was USAID ${ }^{53}$ - an entity established by president Kennedy in 1961, falling under the US Secretary of State's direction, and self-described as an independent federal government agency that supports American foreign policy goals by providing economic, developmental, and humanitarian assistance. ${ }^{54}$ Its foreign assistance policy entails two explicit goals of expanding democracy and free markets and improving the standards of living in the developing world. ${ }^{55}$ Explicitly, its 1984 'Private Enterprise Development' policy paper encourages economic liberalization, reliance on competitive markets, private enterprise for productive growth, self-sustaining income, and market-based job production. Reflecting a Hayekian constitutionalism, these strategic goals are said to create a society in which individuals have the freedom of economic choice, of ownership of the means of production, to compete in the market place, to take economic risk for profit, and to receive and retain the rewards of economic decisions. As we see, focusing on the alteration of social relations of production is more than an analytical tool for historical materialists, but in fact the goal of USAID. 
In Costa Rica, a key function of USAID was to secure domestic support and minimize social resistance. ${ }^{56}$ The way USAID managed has been dubbed the "parallel state" by John Biehl, economist and advisor to president Arias (1986-90), stating USAID restructuring efforts constituted an American attack upon Costa Rica's quiet socialism. ${ }^{57}$ Made up of a set of USAID-created and financed private institutions, including a foreign investment agency, university, road construction company, and banks, the parallel state duplicated and weakened existing Costa Rican state institutions. One primary importance was the creation of foreign investment opportunities by underwriting and financing the privatization of SOEs, encouraging the deregulation of banking, offering neoliberal technical advice, and placing guarantees and insurances on foreign investment. ${ }^{58}$ Initial USAID restructuring loans, which by the mid-1980s were converted largely into grants designed to bypass legislative (read: democratic) approval, were offered in tandem with IMF and WB funds. As such, neoliberal restructuring ensued via the cross-conditionality and coordination of neoliberal structural adjustment programs (SAPs) between the UEls engaged in Costa Rica and domestic social forces. ${ }^{59}$

\section{Restructuring Class-Compromises}

To help appease popular dissent, targeted USAID-supported social compensation was employed by both PLN and PUSC post-1980s administrations. ${ }^{60}$ As 1980s USAIDCosta Rica director Daniel Chaij acknowledged, support for social compensation was imperative because the economic program was certain to impoverish certain people. ${ }^{61}$ To this end, president Monge provided food aid, financial credits, and job training to campesinos, later president Arias offered additional housing compensation programs and basic education programs, and president Calderón continued compensation that attempted to shield the poorest of the poor and smooth the costs of continued adjustment. $^{62}$ True to neoliberal ideology, many social compensation packages were served out through the private sector, effectively transferring public monies directly to the private sector. ${ }^{63}$ Where cuts or the elimination of state subsidies of traditional agriculture for both export and domestic consumption occurred, USAID funded non-traditional agricultural exports to help fill the labour gap and re-orient the economy. ${ }^{64}$ In part, this mandate was allocated to CINDE (Coalition to Promote National Development and Exports) ${ }^{65}$ to help reorganize how cooperatives, small-businesses, campesinos, labour, artisans, and women produced goods and to orient their production towards the export market. $^{66}$

To further shape the processes of social reorganization and institutionalize popular dissent, USAID also created the 'shock-absorbing' umbrella organization Association of Costa Rican Development (ACORDE) in 1986 to finance, organize, and exert ideological influence upon existing non-governmental organizations (NGOs). ${ }^{67}$ With US dollars in hand, ACORDE quickly overshadowed established women's and local developmental NGOs, who had previously received USAID funds directly with fewer strings attached but who were now cut off - in other words, for larger social projects, the ideologicallycharged ACORDE had become the only game in town. ${ }^{68}$ So too was neoliberalism furthered via a free-market education strategy, wherein USAID adopted a relatively aggressive position by establishing a private university (EARTH), funding a private religious school, supporting private-school library improvements, and financing the printing of 'democracy' school textbooks. ${ }^{69}$ Post-secondary scholarships were also made available to pro-American Costa Rican students to study the logic of the private sector in the USA. ${ }^{70}$ 
The reorganization of state power also came in the form of restructured public sector employment such that employment levels were in fact not drastically altered from 198088 , as the public/private employment relation remained relatively stable. ${ }^{71}$ That is, neither the distribution of public expenses nor public employment levels show that there was a drastic reduction in the government's participation within socio-economic matters. ${ }^{72}$ However, reconfiguration did occur in the form of an inward shift and centralization of power toward more economic and financial institutional apparatuses. This power shift largely occurred between 1980-88 when it was only the central government that realized an increase in spending relative to GDP whereas other public and semi-autonomous government institutions realized overall decreases. ${ }^{73}$ On the other hand, while public labour power was centralized much of labour's overall post-war power waned. From 1980-86, the majority of union-based activity was displaced in the private sector by the "solidarismo" (solidarity) movement - a type of worker-patron labour organization sponsored by business - that was linked to the post-war catholic anti-communist movement. ${ }^{74}$ While solidarismo permitted certain worker benefits to be accorded, the main difference is that individual employees negotiated directly with their employer so that class was not the basis of organization. ${ }^{75}$ The growth in solidarismo has been phenomenal - from only seven percent of negotiations between labourer and employer in 1980 to fifty-one percent in 1986; while in 1994 there existed 600 unions, there were 1694 solidarismo associations. ${ }^{76}$ So successful was solidarismo that this form of labour organization was exported to other Central America counties and México. ${ }^{77}$ More importantly, solidarismo has become the labour association of choice in the 1990s for over ninety percent of incoming multinational companies. ${ }^{78}$

\section{Popular Resistance}

While USAID-sponsored state restructuring was designed to mitigate resistance (and boost profitability), these efforts to shift power relations within Costa Rica could not eliminate class struggle. Popular dissent has manifested through various forms of social resistance from liberation theology (active in defence of the poor during the crisis years of 1980-85) to women's social movements that rose up in response to their increasing marginalization within the newly so-called 'democratized' economy. ${ }^{79}$ Often at the forefront of popular resistance are the broad-based rural campesino movements composed of largely of small-farmers and peasants. ${ }^{80}$ Campesinos marched, blocked highways, and conducted sit-ins at government buildings in protest of social program cutbacks and in efforts to preserve their livelihood and existing class compromises. To this end, the rural poor formed domestic alliances with wealthy farmers, negotiated with politicians, and first recruited, then rejected, charismatic outsiders who came to live among them and to speak in their name. Despite cross-class alliances, confrontation between the capitalist power bloc and small farmers occurred. In 1988, amidst an intraand inter-organizational political setting, the Santa Cruz, Guanacaste, strike occurred where a few government buildings were occupied by several dozen angry peasants. While the direct action led to an increase in cheap credits for peasants and, thus, in some small way softened economic restructuring, so too did the direct action result in additional government repression with, for example, the arrest of peasant leader Marcos Ramírez following the occupation. Over time, given USAID social compensation and the structural power of capital, peasant organizations were forced to shift from confrontation to negotiation. The downgrading in resistance strategies is made all the more understandable given the fact that the so-called US "Food for Peace" aid programme effectively wiped out thousands of local producers and destroyed the nation's food selfsufficiency by dumping massive amounts of cheap corn, wheat, and rice onto the Costa Rican market. ${ }^{81}$ That is, by eliminating their material basis for production and continued 
self-sufficient existence, US food-aid also eliminated much of the peasants' material basis for resistance to neoliberal adjustment.

\section{Breaching the National Banking System}

Originally hailed in 1948 as a staple of Costa Rican national development and for its 'democratization of credit', the National Banking System (SBN) came under intense privatization/denationalization pressure due to the significance of capital mobility within neoliberal financial orthodoxy and to providing benefits for domestic capitals seeking additional credits. $^{82}$ Eduardo Lizano Fiat (Central Bank president, 1984 to 2002) summarized the renewed financial orthodoxy, arguing that 'you cannot expect to have a vigorous business sector if you don't have a vigorous banking system, and you cannot build a modern industrial sector based on the four state banks. ${ }^{, 83}$

To initiate SBN privatization, a neoliberal coalition formed BANEX - a bloc of Costa Rican capitals and political elites composed of private bankers, industrialists, and coffee exporters who were seeking injections of fresh capital in the midst of the 1979-1982 world recessions. ${ }^{84}$ The BANEX bloc was viewed as a potential domestic ally for diversifying Costa Rica's export base and liberalization reforms by USAID, who made an initial $\$ 10$ million loan to BANEX in 1981 to be used exclusively as a private enterprise 'special credit line'. ${ }^{5}$ Daniel Chaij, then USAID director, subsequently initiated bi-weekly breakfast meetings with BANEX from which the USAID's offer to fund CINDE arose, with a board of directors selected during USAID/BANEX meetings. ${ }^{86}$ Additional efforts to breach the SBN had also begun to crystallize in 1982 when the USAID provided over $\$ 60$ million in incentives towards financial reform that allotted private banks favourable access to exchange rates that paralleled those available to state-owned banks through the Central Bank. ${ }^{87}$ Financial liberalization pressure did not relent when, in 1984, the important Money Law (Ley de la Moneda) was passed after twenty-three hours of straight legislative deliberation amidst intense pressure from President Monge, PLN ruling elites, state technocrats, domestic capitals, US ambassador Winsor, La Nación ${ }^{88}$, USAID director Chaij, pressing IMF conditionality, and rumours of a coup. Once passed, the Money Law effectively breached public controls on domestic savings by allowing private banks to receive term deposits of more that 180 days and by permitting certain transactions in US dollars. ${ }^{89}$ This was a victory for both domestic and foreign capitals that stood to benefit from liberalization. In the lead up to its passing, both used the other to obscure the fact each wanted these reforms.

Into the late-1980s the IMF maintained denationalization pressure making the approval of the Modernization of the National Banking System Act (1988), which sought to further deregulate the banking sector, a requirement of Costa Rica's second structural adjustment loan. ${ }^{90}$ The 1988 Act shifted state power configurations by removing the Minister of Planning and the Minister of the Economy from the Central Banks' Board of Directors, which had hitherto favoured social development over monetary considerations, handing the majority of Board seats to the national private sector. ${ }^{91}$ So too did the 1988 Act now guarantee deposits (notably following the October 1987 Wall Street crash) in private banks and finance companies by the state. The SBN's originally intended 'democratization of credit' now had been replaced by the 'socialization of risk.' This means, as Ottón Solís put it, that 'profits are privatized while losses are the responsibility of the state. ${ }^{92}$ Following subsequent SBN reforms in 1995 that allowed private banks to compete on equal footing with the three remaining state banks, PLN president Figueres attempted to sell these remaining state banks in 1997 . The sell-off has not yet occurred as it continues to be a socially contentious issue. Nonetheless, 
there has been an explosion of over twenty private commercial banks and financial institutions that are now regulated by the Central Bank through the General Superintendent of Financial Entities (SUGEF). Of these, the largest private banks include Banco Interfin, Banco San José, Banco Banex, BanCrecen, and the global Canadian bank, Scotiabank.

\section{State Restructuring as Transnationalisation or Internationalization?}

The role of UEls and the parallel state, renegotiated class compromises, popular resistance, and an emergent financial orthodoxy are historically contingent moments that initiated, shaped, and modified the emergence of Costa Rican neoliberalism within the context of a capitalist world market. The broader implications of these changes have become a point of debate within historical materialism. Does neoliberalism represent emerging transnational or intensified international processes? On the side of transnational processes, W.I. Robinson's (2003) exceptional analysis of Central America suggests we are witnessing an epochal shift and the reorganization of social structures everywhere with globalization. While there is no space here to give justice to the richness and nuances of Robinson's thesis, he signals two pivotal points: (1) the rise of transnational capital and (2) the supersession of the nation-state as the axis of world development. ${ }^{93}$ New patterns of accumulation and production have been made possible by technology that have helped mold the world into a single, functionally integrated global system. Global capitalism is defined as the transnational integration of national economies related through external exchanges. A new capital-labor relation, shaped by the relative power of global capital over global labor, has been fixed under associated patterns of flexible accumulation. Transnational capital has emerged as the dominant fraction of capital. Nation-state institutions are being superceded by a set of transnational institutions. Indeed, a new transnational social structure is emerging wherein the state is no longer the appropriate unit to examine the global political economy. As such, Robinson posits the transnational state as a constellation of class forces and relations made up of a set of supranational political and economic institutions and practices that transmit the transnational capitalist agenda within now captured and reorganized nation-states everywhere. For Costa Rica, it is yet another local state captured by transnational fractions that then use the state to globalize the country. ${ }^{94}$

While Robinson and I emphasize many of the same historical develops, several points of theoretical contention arise that can only be highlighted but which are supported within my broader analysis. First, I suggest that capital has not yet 'transcended' and is as yet not de-linked from states everywhere. While capital has been global from its inception, profits are still realized, contracts and property protected, money guaranteed, labor disciplined, social and class reproduction occurs and is reproduced, and the international accumulation of capital carried out within domestic spaces, not transcendental ones. ${ }^{95}$ It remains within and across domestic spaces that class struggle rages and strategies are institutionalized. Second, while Robinson is clearly sensitive to the capital-labor relation, he nonetheless overemphasizes the agency of the capitalist class, specifically his dominant transnational fraction. ${ }^{96}$ Be it a strategic focus or not, this freezes the capitallabor relation and functionalizes the state as a tool of transnationals. By fetishizing the power of transnationals, inter-capitalist conflict globally and within domestic power blocs seems to wither away. In this sense, not only is it misrepresentative of capitalist competition but it becomes almost impossible to see how change and/or crisis can occur. Third, it is only by fetishizing transnational capitalist power as embodied within 'capital alone' that Robinson can posit the transnational state as a transmitting agent. However, he cannot begin an analysis of 'capital' and 'state' based on the social form 
and then suddenly allow that capital-labor relation to slip away within a supposed 'trans'national space or state. Thus, while Robinson agrees with Nicos Poulantzas that the state is a social relation, ${ }^{97}$ the TNS itself cannot be the embodiment of transnational capital alone if he wishes to remain true to the social form. Moreover, even to begin by grafting a Poulantzian state onto a transnational one is an exceedingly problematic even more so since, as Robinson acknowledges, the TNS has not yet materialized.

To avoid these problems and maintain the social form and class struggle as central to historical materialist analyses, neoliberal state restructuring is better conceived as 'internationalisation,' a process which has yet to occupy a fictitious space beyond states. $^{98}$ While at first a reaction to crisis, the internationalization of the state has become an increasingly structural feature of neoliberalism wherein the institutional form of state has come to accept responsibility for managing its domestic capitalist order in a way that contributes to the overall management the international capitalist order. ${ }^{99}$ In the case of Costa Rica, as we know, structural adjustment has been facilitated by the IMF, World Bank, USAID, etc., but this does not imply that these institutions have transcended or de-linked from domestic interests or that neoliberalism is a transnational dictate. Rather, internationalization is such that domestic and foreign capitals become linked within power blocs - for reasons including access to labor, protection of private property, realization of profits, guarantee of contracts, and security of money to name but a few. Rather than a smooth transnational transitional process, competing domestic capitals try to shape to their advantage the interventions of international financial institutions just as much as competing foreign capitals do. Historical analysis illuminates the real contours of how this plays out differently in different places.

We can see this domestic specificity in efforts to privatize the national banking system (SBN), a process which is located relative to two broader and interrelated aspects of US imperialism. On the one hand, we recognize aspects of 'financialization': ${ }^{100}$ the post1980s increasingly structural feature of speculative capital accumulation through credit practices. On the other hand, we recognize aspects of the Dollar-Wall Street Regime (DWSR): the essence of the emergent global dynamic wherein the centrality of the dollar directs people towards Wall Street for finance and the strength of Wall Street, as a financial centre, reinforces the dollar as an international currency. ${ }^{101}$ Turning to the domestic sphere, we see how USAID financial involvement was formidable and achieved much in terms of gaining domestic allies and overcoming some of the harsher moments of crisis and neoliberal restructuring. Via this US-sponsored transfer of money to the capitalist class, domestic and foreign capital enjoyed many benefits in Costa Rica through new and safe capital valorisation opportunities. In this we see the parallel state as an institutional expression and form of US imperial power that was also enjoyed by domestic elites - by design. This power was used to alter production and power relations within the Costa Rican, that is, power relations within the domestic power bloc, between the power bloc and popular classes, and within popular classes thereby allowing for more effective and legitimate intervention in economic restructuring. In this sense, pre-existing Costa Rican structural dependencies, such as an agro-export economy and international debt financing were altered and grafted-over by a new and emerging SAP-dependency. ${ }^{102}$ In short, the above serves to illustrate that whatever neoliberal reforms the American and domestic power blocs wanted done still had to occur through and be institutionalized in the Costa Rican state in order to overcome existing class compromises and gain and maintain legitimacy (i.e., neoliberalism is not merely imposed). The Costa Rican institutional form of state was involved because of its role in the organization of competing capitals, control of labour, and its mediatory role 
between capital and labour. The question remains, however, some twenty years on from the initial 1980s crisis and 100-Day Plan: has neoliberalism succeeded or failed for the majority of Costa Ricans?

\section{The Lessons in Twenty years of Neoliberalism}

\section{USAID Lessons Learned}

Ostensibly as a result of fifty years of intervention, USAID suggests that its financial and technical assistance has significantly contributed to Costa Rican welfare as testified to by a healthier, wealthier, and better educated populace characterized by a more equitable income distribution and a better maintained environmental base than it would have had without USAID. ${ }^{103}$ Costa Rica has met the expectations of Americans because it remains strongly democratic and respects human rights (i.e., civil and political rights have been maintained). Citing Chile as a more problematic experience with neoliberal adjustment, Costa Rica serves as a model for Latin America because, since the challenges of the early 1980s, its economy has successfully integrated into the new world economy while being a leader in ecosystem management. For USAID, if only 'all developing countries had matched Costa Rica's progress on economic, social, and political indices, there would be fewer complaints about the effectiveness of foreign aid.' Indeed, the American public and Congress should consider USAID successful to the extent that Costa Rica no longer requires American economic aid. This is especially so if Costa Rica were itself to assist in the development of its poorer neighbours, proffering 'the ultimate evidence to the American public that U.S. assistance had succeeded in broad moral terms.'

The heralded success of USAID in Costa Rica, thus, is immensely relevant to other Latin American countries. Hailed as the best Latin American example of global economic integration and solidified democracy, certain generalisable lessons have been deduced by USAID. These lessons include USAID comparative advantage as a donor-aid agency, the value of good governance and institutional-building, the critical importance of a willing elite and pragmatic government towards restructuring, and the general success of liberal economic policy. With liberal economic policy, there is a need to attract export-oriented foreign investment, to maintain good macroeconomic policies (e.g., a favourable exchange rate for exporters), and generally sound macroeconomic policies for a predictable business environment. Early trade liberalization is less critical so long as exporters have access to inputs at world prices. Finally, USAID has learned that countries must 'seize the day', as Costa Rica has, so as to take advantage of opportune access to global markets to expand export growth.

The proof is that Costa Rica has experienced dramatic growth in exports over the past three decades evidenced by new export products that have supplemented its traditional agricultural exports of coffee and bananas. In hard numbers, from 1970 to 2000 exports from Costa Rica grew from $\$ 281$ million to $\$ 7.45$ billion. Much of this has been as a result of the apparel industry's rise from one percent of exports in 1970 to 17 percent in 1995 (although down to 11 percent in 2000) and 'other manufactures' rise from zero percent in 1970 to 17 percent in 1995 and 41 percent in 2000 (due largely to Intel, whose exports reached 36 percent of all exports in 2002). Meanwhile, traditional exports have fallen from 60 percent in 1970 to 12 percent in 2000 . USAID also notes that tourism has risen in importance as well as several other products such as cut flowers, ornamental plants, and melons. Services such as computer programming and cosmetic surgery also have become sources of export earnings. As a result, by 1995 Costa Rican 
exports outside of Central America, still mostly directed towards the USA, were dramatically larger than they had been in 1983. This increased diversity of export products (if not destinations) has altered Costa Rica's economy such that, argues USAID, the world collapse in coffee prices by half between 2000-02 did not crumble its economy as it would have three decades earlier. Indeed, Costa Rica has clearly achieved what most less-developed countries want - a dramatic change from production of one or a few primary products to competitive production of manufactures and services in world markets.

The enthusiasm of USAID, however, begs the question of whether the Costa Rican experience is in fact generalisable to the rest of Latin America. Intuitively, this is doubtful, for not all countries can become uber-export platforms and minimal importers, much less doing so successfully without receiving the fifth largest per capita amount of USAID dollars - a condition of Costa Rica's success that is certainly not generalisable to all others. ${ }^{104}$ Rather, the reality of Costa Rica and the rest of Latin America points more to the general failures of neoliberal reform than its success.

\section{Lessons Left Out}

While Costa Rica's successes should not be lightly disregarded, what USAID has not mentioned are neoliberalism's short-comings in Costa Rica, partly testified to by the post-1980s wild swings in gross domestic product (GDP) growth rates. The swings range from eight percent in 1983 and to less that one percent in 1984, from two percent in 1990 and to eight percent in 1991, from less that one percent in 1996 and approximately eight percent from 1997-1999 to once again crashing down to one percent by the end of 1999, 1.8 percent in 2000, 1.2 percent in 2001, and 2.8 percent in 2002. ${ }^{105}$ Putting into sharp relief this generalized instability, a run on US dollars investments early in 2004 saw over $\$ 1$ billion and 15000 investors leave resulting in capital and accumulated interest losses, once contained, of over $\$ 123$ million. ${ }^{106}$ By contrast, the pre-1980s debt crisis period, or the so-called Golden Era of state-led development, witnessed much more stable growth: from 1962 to 1979, GDP growth remained stable and largely between five to eight percent per year with minimal inflation. In the post-1980s period Costa Ricans are living in a constant state of crisis, despite being a showcase of US- and IMF-led post-1980 neoliberal reforms and despite being one of the highest per capita recipients of USAID dollars in the world.

The lessons left out by USAID in its dubious celebration of Costa Rica are even more suspect when the net is cast wider. As Dani Rodrik argues, not only has the Washington consensus model run out of excuses but the financial system is essentially broken; indeed, anyone 'who still thinks this is an efficient system for resource transfer is mad.'107 Joseph Stiglitz also weighs in within the mainstream arguing that the promises of neoliberal reform have not produced their promised rewards of rapid and sustained economic growth. ${ }^{108}$ Latin Americanists Judith Teichman and Carlos Sojo agree. Looking at Mexico and Argentina, Teichman (2002) argues that Latin America exemplifies the failure of market reforms, reforms that have not provided sustained growth and equitable prosperity. Rather, in most Latin American states, inequality and poverty have worsened while unequal power structures and political practices persist. Big business alone has been able to take advantage of export-promotion, pushing aside small- and medium-sized enterprises, and undermining the government's ability to undertake more equitable reform. Costa Rican scholar Sojo (2004) similarly argues neoliberal development in Latin America has faltered, criticizing the dominant marketbased, export-oriented strategy of the last two decades that has not resulted in 
significant gains for Latin America's population. Rather, poverty reduction needs to be addressed differently as part of social policy and be understood as the result of a sustainable means for social mobility both inter- and intra-generationally over the longterm. Sojo, like Teichman, concludes that the neoliberal export-oriented model has created 'socially-concentrated economic growth.'

Reinforcing their condemnation of neoliberalism we can look to the 2003 ECLAC report, Preliminary overview of the economies of Latin America and the Caribbean 2003. It illustrates that across Latin America and in the last twenty years economic growth has been unstable, highly vulnerable, and running an ambiguous path. Over and above the lost decade of the 1980s, the late-1990s and start to the new millennium have further exemplified this turbulent failure, prompting ECLAC to dub these years another 'lost halfdecade.' The Latin American and Caribbean region grew by 1.5 percent in 2003 while the region's GDP per capita remained flat at 1.5 percent below 1997 levels - meaning six years of negative per capita growth. There are now 20 million more poor people in Latin America than in 1997, mirroring the two percent increase in unemployment to 10.7 percent (only Costa Rica, Colombia, and Ecuador improved, though almost imperceptibly). There remain 227 million people, or 44 percent of the population, below the poverty line. While outlooks appeared brighter for 2003, there remains wide uncertainty as to a broad-based global recovery. Regardless, capital continues to flow out of Latin America, the total for 2003 being $\$ 29$ billion or 6.9 percent of the region's total exports of goods and services! Gross external debt as of December 2003 is at $\$ 744$ billion, representing a 2.4 percent increase after some decline in 2000 and 2001, which had been 'manageable' due to lower interest rates. This, however, may explode once again as the USA warns of interest rate increases. Amidst this disarray, it ought not to be forgotten that the IMF has introduced 'collective action clauses' following the deferral of its sovereign debt restructuring mechanism (i.e., state bankruptcy law), which give greater power to debt-issuing governments and investors to expedite the further restructuring of indebted states through dispute settlement processes, if necessary. ${ }^{109}$

Within this 'unpleasant' Latin America context, Costa Rica, as USAID is at pains to illustrate, has done well comparatively. As ECLAC notes, Costa Rica has been stronger than other Central American states with a 2003 GDP growth rate of 5.6 percent, largely due to fruit and the high tech industry (i.e., Intel). Unemployment has at least not increased in the last half-decade. Moreover, Costa Rica is among the most democratically stable Latin American states. For investors, the protection of private property, investment, and the rule of law appear to be under no threat. However, as seen above, Costa Rica, like much of Latin America, has failed to overcome crisis. That is, global economic instability is being managed but not resolved. ${ }^{110}$ The role of the post-1980s institutional state-form now rests not so much in preventing these predestined, if not predictable, crises but in containing them, something which is given only in extreme instances to the UEls emphasized within Robinson's transnational state.

Unable to fully resolve the social contradictions that arise with socio-economic restructuring, what has come to be a relatively stabilized 'state of crisis' still manifests in popular dissent. Recently, a group of Costa Ricans along the poorer Caribbean Coast and the Natural Resources Defense Council have been leading an international campaign to prevent the establishment of ecologically harmful foreign-owned petroleum drilling in Costa Rica - drilling that has political ties with President George W. Bush. ${ }^{111}$ This particular struggle has a history rooted in the earlier privatization of the port in Limón and closing of the railway, the culmination of which was a violent protest in June 
1996. ${ }^{112}$ Just a couple years earlier, a historical class struggle was fought against the third IMF SAP and PUSC president Calderón's (1990-94) calls for privatization of Costa Rica's electrical and telecommunications industry, ICE - the result of which was a shortlived working class victory and halted privatization plans. ${ }^{113}$ Privatization calls were raised again in 1998-99 by president Rodríguez (1998-2002) but again put to rest with national discontent. ${ }^{114}$ Less successful was the 1995 national teachers' strike under PLN president Figueres (1994-98), which closed schools for thirty-two days but that failed to achieve most of their demands aimed at compensating the drastic cuts in the education system. ${ }^{115}$ However, public labour unions did effectively rally and organize an information campaign and staged a strike in October 2001, under PUSC president Rodríguez, to protest the proposed privatization of the national water and sewage systems (AyA). ${ }^{116}$

Amidst these social contradictions, neoliberalism has pressed forward and deepened institutionally. Costa Rica and Canada exchanged ratifications of a new Free Trade Agreement on 1 November 2002 in Quito, Ecuador - at the $7^{\text {th }}$ Ministerial Reunion for the Free Trade Area of the Americas. ${ }^{117}$ The symbolism of both the new FTA and the timing of exchange served as capitalist libations towards the broader FTAA negotiations. $^{118}$ Just the previous day, the US government announced how the FTAA was fundamental to its ability to compete at a global level with other large economic blocks such as Asia and the European Union. ${ }^{119}$ However, four days later in the $8^{\text {th }}$ State of the Nation Address, the Costa Rican government stated that each year is less and less equitable and that the country continues to suffer from the consequences of faltering social programs, especially in education, and its export-promotion strategy that has not brought greater social benefits. Rather, a concentration of exporters has occurred while smaller producers suffer. ${ }^{120}$ The week following, ironically, during a statesponsored export-promotion exposition, Alberto Trejos, current Minister of Trade, testified to the importance of intensifying export promotion to countries with which they hold free trade agreements. ${ }^{121}$ Indeed, Trejos calls the new Central American Free Trade Agreement (CAFTA) deal signed in January 2004 an 'excellent agreement'. ${ }^{122}$ Just one month earlier, however, in protest to US imperial pressure to privatize ICE (again) and to deregulate the insurance sector, Costa Rica had pulled out of CAFTA negotiations. Recalling their 1994 and 1999 resistance to ICE privatization, labour unions and social groups have vowed to fight CAFTA approval in Congress, stating protest is inevitable. Even former conservative president Carazo (1978-82), who expelled the IMF in 1981, has come forward saying CAFTA is a mystery and a threat to the public. While neoliberalism has become the structural feature of contemporary capitalism, it does not remain uncontested and outside of capital and labor class conflict.

\section{Conclusion: New Imperialism and Costa Rica}

It's the neoliberals who are anti-global. They're the ones who'll end up destroying the world.

$$
\text { Hugo Chavez, } 2001^{123}
$$

USAID claims of Costa Rica's exemplar status are dubious when examined critically and within the wider lens of Latin America's neoliberal experiences. Why, then, does USAID bother? Costa Rica, at a mere fraction of the American GDP, is not of any decisive economic benefit - the USA and the global economy could certainly persist without it. Nonetheless, Costa Rica's heralded successful global integration is of vital importance to critical scholars as an example of the new imperialism. This is so because the 
reconfigured Costa Rican state engenders material, institutional, and discursive moments of a reconstituted American empire. Materially, US tax-based financial resources have had very real economic and developmental effects in Costa Rica, albeit volatile, and by necessary extension on everyday Costa Rican life mitigating the worst of popular resistance in the processes of internationalization. ${ }^{124}$ The transfer of resources from the public to the private sector has been also used to prompt, support, and further macroeconomic structural adjustment and neoliberal reform as part of the wider puzzle of financialization. Associated vanguard processes of privatization, as Stuart Hall suggests, facilitates legitimacy and class-based benefits, displacing ' $\ldots$ an existing structure of oppositions - 'them' versus 'us'. It sets in its place an alternative set of equivalents: 'them and us equals we.' Then it positions we 'the people' - in a particular relation to capital: behind it, dominated by its imperatives (profitability, accumulation): yet at the same time yoked to it, identified with it. ${ }^{125}$ Institutionally, USAID has learned valuable lessons about how to facilitate and preside over neoliberal state restructuring through, for example, the centralization of power in the Executive and Central Bank and the construction of a parallel state. Civil and political rights, that is, formal democracy and private property, are valued and safeguarded far more that any form of substantive democracy. What is more, Costa Rica demonstrates the importance of maintaining an 'effective' institutional state through transition (i.e., internationalization, not transnationalization) - a growing concern of the WB, IMF, and the USA since the late1990s. Discursively, hailing Costa Rica as the Latin American exemplar of successful global integration becomes a powerful 'how possible' of development that buttresses claims of success by capital and neoliberal state technocrats. This is exceedingly important because the aims of neoliberal reforms can only be pursued to the degree that they can be rendered legitimate. ${ }^{126}$ These three moments thus represent a class-based form of collective agency seeking to shape to one's benefit the historical-structural sites of social action and reaction while overcoming barriers to progressive capital accumulation. Integral to this analysis is recognising how the Costa Rica state-as-asocial-relation has come to envelope crisis so as to become a material, institutional, and discursive mediating buffer within the world market. The management of the global economy has now increasingly shifted from the USA and other advanced capitalist states to more aggressively include all emerging markets and effective states. This illustrates the core of reconstituted US power and internationalization, namely, how states are charged, at least in the first instance, with managing recurrent crises within neoliberal financial orthodoxy.

This shift implies a form of imperialism that differs from classical forms then premised on a world that was not yet predominantly capitalist. ${ }^{127}$ The new imperialism does not depend on direct military interventions or direct political control, although these may coexist. Rather, power is exercised by a dominant hegemon, like the USA, such that it directs the global economy and instructs others how to serve the interests of its own domestic capitals by manipulating debt, trade rules, the financial system, and, of course, foreign aid. ${ }^{128}$ This power does not mean the USA can simply resolve the contradictions of capitalism in the precarious balance between their particular needs and the general needs of global capitalism - these must be constantly managed, a job assigned primarily to domestic state managers, then more generally to the US Treasury and to UEls, such that effective states are indispensable. Indeed, '[i]t would not be too much to say that the state is the only non-economic institution truly indispensable to capital' as neoliberalism and global capital are by no means able to eliminate the state's social functions. ${ }^{129}$ Because this is a process of altering social relations it demands renegotiated class compromises such that the opportunities for progressive 
accumulation do not occur 'beyond' the state, but rather occur between states and are state-authored. ${ }^{130}$ The state organizes class conflict while intervening in the global and local economy, the benefits of which become evident as the USA virtually alone has prospered among advanced capitalist economies ${ }^{131}$ while income gaps worsen globally.

In conclusion, then, we can see the importance of Costa Rica as a case where substantial resources were poured into one state in order to make neoliberal restructuring work and seemingly work legitimately. Aside from immediate profit, the benefits are that Costa Rica can be held up as an exemplar to the rest of Latin America and used to condone all sorts of restructuring interventions and unequal property relations. The Costa Rican state, rather than being bypassed, has been central to these processes of reconstituted imperialism. The foregoing thus points to the continuing importance of class-based analyses - analyses, however, that consider the material, institutional, and discursive moments of power and domination in a historical context of an empire of capital. In contrast, through their highly normative and narrowly prescriptive foundations, liberal traditions merely obscure the power relations inherent in global capitalist restructuring, seeking to reinforce, rather than liberate, pre-existing and exploitative social relations. For mainstream institutionalists, the failures of capitalism are simply failures of policy that can be fixed over time. For historical materialists, the failures of capitalism are inherent and objective to the capital-labour relationship and associated unequal distributional arrangements. These unequal structural power relations undermine, but do not eliminate, everyday struggles for organisation and emancipation. However, working class strategies must be conceived of in the context of neoliberalism as a now historically stabilized and distinct phase of capital accumulation. 


\section{Bibliography}

Agosin, Manuel R. and Ricardo Ffrench-Davis 1995, 'Trade Liberalization and Growth: Recent Experiences in Latin America,' Journal of Interamerican Studies and World Affairs, 3.

Albo, Gregory 2003, 'The Old and New Economics of Imperialism,' in Socialist Register 2004, edited by Leo Panitch and Colin Leys, London: Merlin Press.

Andrews, David M., C. Randall Henning, and Louis W. Pauly 2002, 'Monetary Institutions, Financial Integration, and Political Authority,' in Governing the World's Money, edited by David M. Andrews, C. Randall Henning, and Louis W. Pauly, London: Cornell University Press.

Barry, Tom and Deb Preusch 1988, The Soft War: The Uses and Abuses of U.S. Economic Aid in Central America, New York: Grove Press.

Bejarano, Oscar 1992, 'El Solidarismo Costarricense,' in El Nuevo Rostro de Costa Rica, edited by Juan Manuel Villasuso, Heredia, Costa Rica: CEDAL.

Booth, John A. 1998, Costa Rica: Quest for Democracy, Boulder, CO: Westview Press. Bonefeld, Werner 1999, 'Notes on Competition, Capitalist Crises, and Class,' Historical Materialism, 5.

Brenes, Lidiette 1990, La Nacionalización Bancaria en Costa Rica: Un Juicio Histórico, San José: FLACSO.

Brenner, Robert 1998, 'The Looming Crisis of World Capitalism: From Neoliberalism to Depression?' Against the Current.

Bulmer-Thomas, Victor 1987, The Political Economy of Central America since 1920, New York: Cambridge University Press.

Cajiao, María Virginia 2001, 'Situación legal de las exploraciones petroleras en el Caribe tico,' Ambientico, 90.

Cheru, Fantu and Stephen Gill 1997, 'Structural Adjustment and the G-7: Limits and Contradictions,' in Globalization, Democratization, and Multilateralism, edited by Stephen Gill, New York: St. Martin's Press.

Clark, Mary 1997, 'Transnational Alliances and Development Policy in Latin America: Nontraditional Export Promotion in Costa Rica,' Latin American Research Review, 32, 2.

Clarke, Simon 1988, 'Overaccumulation, Class Struggle and the Regulation Approach,' Capital and Class, 36.

Colás, Alejandro 2002, 'The Class Politics of Globalisation,' Historical Materialism and Globalization, edited by Mark Rupert and Hazel Smith, New York: Routledge.

Corbridge, Stuart, Nigel Thrift, and Ron Martin (eds.) 1994, Money, Power, and Space, Oxford: Blackwell Publishers. 
Cruz, Paquita and Alda Facio 2000, 'Vientos de Modernización Sacuden a Costa Rica,' Mujer/Fempress, 8.

Cypher, James M. 1989, 'The Debt Crisis as 'Opportunity': Strategies to Revive U.S. Hegemony,' Latin American Perspectives, 16, 1: 52-78.

Duménil, Gérard and Dominique Lévy 2002, 'The Nature and Contradictions of Neoliberalism,' in Socialist Register, edited by Leo Panitch and Colin Leys, London: Merlin Press.

ECLAC, Statistical Yearbook for Latin America and Caribbean 1999.

ECLAC, Statistical Yearbook for Latin America and Caribbean 2003.

Edelman, Marc 1998, 'Transnational Peasant Politics in Central America,' Latin America Research Review, 33.

Edelman, Marc 1999, Peasants Against Globalization: Rural Social Movements in Costa Rica, Stanford: Stanford University Press.

Feigenbaum, Harvey B. and Jeffrey R. Henig 1994, 'The Political Underpinnings of Privatization: A Typology,' World Politics, 46, 2.

Fox, James W. 1998, Real Progress: Fifty Years of USAID in Costa Rica, Center for Development Information and Evaluation (USAID).

Fox, James W. 2003, Successful Integration into the Global Economy: Costa Rica and Mauritius, report prepared by Nathan Associates Inc for USAID/Washington.

Franco, Eliana and Carlos Sojo 1992, Gobierno, Empresarios y Políticas de Ajuste, San José: FLACSO.

Germain, Randall 1997, The International Organization of Credit: States and Global Finance in the World Economy, Cambridge University Press.

Ghosh, J.M. Tanski, and C.E Enomoto 1996, 'Macroeconomic Adjustments for DebtLaden Economies: The Central American Experience,' Social Science Journal, 33.

Goss, Jasper and Douglas Pacheco 1999, 'Comparative Globalisation and the State in Costa Rica and Thailand,' Journal of Contemporary Asia, 29.

Gowan, Peter 1999, The Global Gamble: Washington's Faustian Bid for World Domination, New York: Verso.

Gudmundson, Lowell 1986, Costa Rica before Coffee: Society and Economy on the Eve of the Export Boom, Baton Rouge: Louisiana State University Press.

Hamann, Kerstin and Bruce M. Wilson 2001, 'Surviving the Political Consequences of Neoliberal Policies,' Contemporary Politics, 7:129-47. 
Honey, Martha 1994, Hostile Acts: US Policy in Costa Rica in the 1980s, Miami: University Press of Florida.

International Monetary Fund 2002, Costa Rica: Selected Issues, IMF Country Report, No. $02 / 89$.

Judson, Fred 1993, 'The Making of Central American National Agendas Under Adjustment and Restructuring,' Labour, Capital and Society, 26.

Langley, Paul 2002, World Financial Orders: An Historical Political Economy, New York: Routledge.

Langley, Paul 2003, 'The Everyday Life of Global Finance,' IPEG papers in Global Political Economy, BISA.

Larraín B., Felipe and Luis F. López-Calva 2001, 'Privatization: Fostering Economic Growth through Private Sector Development,' in Economic Growth in Central America: Structural Reform, edited by Felipe Larraín B., Cambridge: Harvard University Press.

Lecuona, Rafael A. and Nasser Momayezi 2001, 'Privatization in Costa Rica: Political and Economic Impact,' International Journal on World Peace, 18: 23-40.

Lehoucq, Fabrice E. 1990, 'Class Conflict. Political Crisis and the Breakdown of Democratic Practices in Costa Rica: Reassessing the Origins of the 1948 Civil War,' Papers in International Political Economy, Duke University Program in Political Economy.

Marx, Karl 1891 [1849], Wage Labour and Capital, pamphlet translated by Fredrick Engels.

Mesa-Lago, Carmelo 2001, Market, Socialist, and Mixed Economies: Comparative Policy and Performance, Chile, Cuba, and Costa Rica, Baltimore: Johns Hopkins University Press.

Molina, Ivan and S. Palmer 1997, Costa Rica 1930-1996: Historia de una Sociedad, San José: Editorial Porvenir.

Panitch, Leo 1994, 'Globalisation and the State,' in Socialist Register, edited by Leo Panitch and Colin Leys, London: The Merlin Press.

Panitch, Leo and Sam Gindin 2003, 'Global Capitalism and American Empire,' in Socialist Register 2004, edited by Leo Panitch and Colin Leys, London: The Merlin Press.

Patomäki, Heikki 2001, Democratising Globalisation: The Leverage of the Tobin Tax, New York: Zed Books.

Poulantzas, Nicos 2000 [1978], State, Power, Socialism, New York: Verso Classics.

Richards, Donald G. 1997, 'The Political Economy of Neo-Liberal Reform in Latin America: A Critical Appraisal, Capital and Class, Spring: 19-43. 
Robinson, William I. 1998, '(Mal)Development in Central America: Globalization and Social Change,' Development and Change, 29, 3.

Robinson, W.I. 2003, Transnational Conflicts: Central America, Social Change, and Globalization, New York: Verso.

Seligson, Mitchell A. and Edward N. Muller 1987, 'Democratic Stability and Economic Crisis: Costa Rica, 1978-1983,' International Studies Quarterly, 31: 301-26.

Soederberg, Susanne 2001a, 'Grafting Stability onto Globalization? Deconstructing the IMF's Recent Bid for Transparency," Third World Quarterly, 22, 5.

Soederberg, Susanne 2001b, 'The Emperor's New Suit: The New International Financial Architecture as a Reinvention of the Washington Consensus,' Global Governance, 7, 4: 453-68.

Soederberg, Susanne 2001c, 'From Neoliberalism to Social Liberalism: Situating the National Solidarity Program within Mexico's Passive Revolutions,' Latin American Perspectives, 28, 3.

Soederberg, Susanne 2001d, 'State, Crisis, and Capital Accumulation in Mexico,' Historical Materialism, 9: 61-84.

Soederberg, Susanne (forthcoming), Transcending Global Governance: Debt, Class, Power, and the New Imperialism, London: Pluto Books.

Strange, Susan 1998, Mad Money: When Markets Outgrow Governments, Ann Arbor: The University of Michigan Press.

Sojo, Carlos 1991, La Utopía del Estado Mínimo: La Influencia de AID en las Transformaciones funcionales e institucionales del Estado Costarricense en los Años Ochenta, Managua: CRIES.

Sojo, Carlos 2004, 'Social Development, Integration, and Public Policies in Latin America,' presentation for the World Bank Group, <http://info.worldbank.org/etools/bspan/PresentationView.asp?PID=1024\&EID=532>

Teichman, Judith 2002, 'Private sector power and market: exploring the domestic origins of Argentina's meltdown and Mexico's policy failures,' Third World Quarterly, 23, 3: 491512.

Valverde R., José Manuel 1993, Proceso de Privatización en Costa Rica ... y la Respuesta Sindical? San José: ASEPROLA/SINDEU.

von Braunmuhl, Claudia 1978, 'On the Analysis of the Bourgeois Nation State within the World Market Context: An Attempt to Develop a Methodological and Theoretical Approach," in State and Capital: A Marxist Debate, edited by John Holloway and Sol Picciotto, London: Edward Arnold. 
Wilson, Bruce M. 1994, 'When Social Democrats Choose Neoliberal Economic Policies: The Case of Costa Rica," Comparative Politics, 26:149-168.

\section{Wilson, Bruce M. 1998, Costa Rica: Politics, Economics, and Democracy, Boulder, Colorado: Lynne Rienner Publishers.}

\section{Wilson, Bruce M. 1999, 'Leftist Parties, Neoliberal Policies, and Reelection Strategies: The Case of the PLN in Costa Rica," Comparative Politics, 32: 752-779.}

\section{Wood, E.M. 2003, Empire of Capital, New York: Verso.}

\footnotetext{
${ }^{1}$ I am very grateful to the referees for their insightful comments as well as to Eric Newstadt (York University) and Alejandro Colás for their helpful input. All remaining omissions and errors are, of course, my own.

2 in Tim Rogers, “Ombudsmen Decry 'Social Exclusion'," Tico Times (30 March 2001).

3 in Judson 1993, p. 162.

${ }^{4}$ In Fox 1998.

${ }^{5}$ Poulantzas 2000; $c f$. Panitch 1994; Soederberg 2001.

${ }^{6}$ Aside from World Bank and IMF documents, additional liberal accounts focusing on market efficiency include: Agosin and Ffrench-Davis 1995, Lecuona and Momayezi 2001, and Larraín B. and López-Calva 2001. From the institutionalist perspective, the neoliberalism-as-policy approach examples are as follows: Wilson 1998, Hamann and Wilson 2001, and Wilson 1999, and Wilson 1994

${ }^{7}$ Robinson 1998, and 2003; Clark 1997.

${ }^{8}$ Drawn from: Poulantzas 2000; von Braunmuhl 1978; Soederberg 2001c, and 2001d; For a similar account of Costa Rica, see Goss and Pacheco 1999.

${ }^{9}$ Drawn from the following: Soederberg 2001d; Clarke 1988; Duménil and Lévy 2002.

${ }^{10}$ Drawn from Panitch and Gindin 2003; Albo 2003; Wood 2003. The new imperialism spoken of here refers to reconstituted American power and associated informal imperial rule, or empire of capital, that must be understood through rejuvenated state theory. To this end, I define the concept of state as a material, institutional, and discursive condensation of a balance of class forces; as such, the state is at core a social relation that implies the capital-labor relation (drawn from Poulantzas 2000; Panitch 1994; Langley 2003).

${ }^{11}$ The world market is aptly described by von Braunmuhl (1978) as, 'an international, state-organized and specifically structured, all-encompassing effective international context of competition, within which statehood arises and consolidates itself and states form their characteristic economic, social and political structure.'

${ }^{12}$ Robinson 2003, pp. 133-34.

${ }^{13}$ A complete analysis of the 1948 civil war is beyond the scope of this paper; suffice it to say that controversy exists amongst Marxist, liberal, and institutionalist analysts as to why crisis occurred and why Costa Rica resorted to violence to resolve its conflict (see Lehoucq 1990; Gudmundson 1986; Seligson and Muller 1987; Wilson 1998; Booth 1998; Bulmer-Thomas 1987).

${ }^{14}$ Goss and Pacheco 1999; also Mesa-Lago 2001. Since this time, Costa Rica has maintained a largely twoparty system: the moderate-left PLN and the centre-right Social Christian Unity Party (PUSC). This recently changed in the 2002 presidential elections when PLN-defector Ottón Solís formed the Citizen Action Party (PAC), making a historic breakthrough by winning 26 percent of the popular vote, causing a run-off vote between the PLN and PUSC. The PUSC leader, Abel Pacheco, took the final vote and remains at the head of the Costa Rica government until 2006.

${ }^{15}$ Robinson 1998; Goss and Pacheco 1999; Gudmundson 1986, p.7.

${ }^{16}$ See Bulmer-Thomas 1987, p. 118, 168, 172; Wilson 1998, p. 107.

${ }^{17}$ Wilson 1998, Ch.4; Bulmer-Thomas 1987, p. 110, 150; Mesa-Lago 2001.

${ }^{18}$ Bulmer-Thomas 1987, p. 111.

${ }^{19}$ Bulmer-Thomas 1987, p. 171.

${ }^{20}$ Bulmer-Thomas 1987; also see Germain 1997.

${ }^{21}$ Goss and Pacheco 1999; Bulmer-Thomas 1987, p. 173.
} 
${ }^{22}$ Wilson 1998, p. 95; Mesa-Lago 2001.

${ }^{23}$ Wilson 1998, Ch.4; Bulmer-Thomas 1987, p. 197.

${ }^{24}$ Mesa-Lago 2001; Bulmer-Thomas 1987, pp. 194-96; Wilson 1998, Ch. 4; Richards 1997, p. 31.

${ }^{25}$ Wilson 1998, p. 107; Bulmer-Thomas 1987, p. 176.

${ }^{26}$ Goss and Pacheco 1999; $c f$. Richards (1997) and links between tax incentives and class-based booms.

${ }^{27}$ Bulmer-Thomas 1987, p. 192

${ }^{28}$ Mesa-Lago 2001; Wilson 1998, Ch. 4.

${ }^{29}$ Bulmer-Thomas 1987, p. 208.

${ }^{30}$ Ghosh, Tanski, Enomoto 1996; Goss and Pacheco 1999.

${ }^{31}$ Valverde 1993, p. 9, 29; Molina and Palmer 1997; Sojo 1991; Wilson 1994, p. 153.

${ }^{32}$ Molina and Palmer 1997, p. 27.

${ }^{33}$ See Brenes 1990, p. 126; Honey 1994.

${ }^{34}$ cf. Cypher 1989.

${ }_{35}^{35}$ Sojo 1991, p. 16.

${ }^{36}$ Carazo in Sojo 1991, p. 16.

${ }_{38}^{37}$ Sojo 1991, p. 17.

38 in Brenes 1990, p. 148.

${ }^{39}$ Seligson and Muller 1987, p. 315.

${ }^{40}$ Sojo 1991, p. 15.

${ }^{41}$ Valverde 1993, p. 14; Sojo 1991, p. 15.

${ }^{42}$ On crises of overaccumulation/overproduction, it is worth quoting Marx at length: 'We thus see how the method of production and the means of production are constantly enlarged, revolutionized, how division of labour necessarily draws after it greater division of labour, the employment of machinery greater employment of machinery, work upon a large scale work upon a still greater scale. This is the law [of competition] that continually throws capitalist production out of its old ruts and compels capital to strain ever more the productive forces of labour for the very reason that it has already strained them -- the law that grants it no respite, and constantly shouts in its ear: March! march! This is no other law than that which, within the periodical fluctuations of commerce, necessarily adjusts the price of a commodity to its cost of production.' (Marx 1891).

${ }^{43}$ Clark 1997; Sojo 1991; Molina and Palmer 1997, p. 29

${ }^{44}$ Drawn from: Judson 1993, p. 153; Bonefeld 1999; Richards 1997; Wilson 1999.

${ }^{45}$ Sojo 1991, p. 18; see also Molina and Palmer 1997, p. 29; While many authors point to the geopolitical significance of the fall of Somoza and the rise of the Sandinistas in Nicaragua vis-à-vis the USAID role in the so-called soft-restructuring of Costa Rica (which I do not dispute), this is a debate that will not be entered into here. Suffice it to say, I do not separate America's interest in Nicaragua's "communist threat" from the wider crises of capitalism and America's reconstituted imperial bid within Latin America.

${ }^{46}$ in Honey 1994, p. 56.

${ }^{47}$ in Wilson 1994, p. 157.

${ }^{48}$ In contrast to institutionalist usages of 'multilateral economic institutions' to describe the IMF, WB, USAID, etc., I suggest they are better understood as UEIs. Doing so helps us recognize that their central, unitary purpose is to act in the interests of capital-in-general, not 'states' understood narrowly as governments, by ensuring progressive capital valorization opportunities. What is more, removing the idea of 'multilateral' helps one see that the IMF, WB, and even USAID do not act just for the "USA" or just for "Costa Rica" understood as black boxes devoid of class struggle but rather UEI power is activated by class agency for the interests of various global capitals. As such, using UEIs helps us to overcome institutionalist understandings of the world economy that reifies states as distinct 'subjects' or 'things' that can act or are acted upon as individual members within the so-called multilateral institutions. Rather, states can be better understood in a Poulantzian sense as a field of struggle and balance of contesting class forces within the wider context of capitalist social relations. For a discussion of MEIs and legitimacy, see Andrews, Henning, and Pauly 2002.

${ }^{49} \mathrm{Cf}$. Soederberg $2001 \mathrm{~b}$.

${ }^{50}$ Drawn from: Honey 1994, p. 62; Sojo 1991; See also Barry and Preusch (1988) for a discussion of the use of USAID funds.

${ }^{51}$ Honey 1994, p. 62.

${ }^{52}$ ECLAC, Statistical Yearbook for Latin America and Caribbean 1999. 
${ }^{53}$ While each of these UEIs are important, I shall be limiting my analysis largely to USAID. This in no way suggests the others' involvement was unimportant, although it should be noted that the US and especially the Reagan administration were quite hostile to the IDB and its sympathy to ISI, and therefore successfully pressured them to conform to the dominant neoclassical and neoliberal views (Cypher 1989, pp. 71-2).

${ }_{54}$ Taken from USAID website: http://www.usaid.gov/about/.

${ }^{55}$ USAID's “Human Rights Policy Determination”, 26 Sept. 1984. Ironically, while the USAID mission is to promote democracy, it was only after of few years of its intensive presence that, in August 1984, Costa Rica neared a coup situation and President Monge called his country into the streets to ward off US pressure for support in the war against the Sandinistas (Honey 1994, pp. 84-5; Molina and Palmer 1997, p. 29).

${ }^{56}$ Drawn from: Goss and Pacheco 1999; Sojo 1991.

57 in Honey 1994, p. 75.

${ }^{58}$ Honey 1994, Ch.3; Sojo 1991; Richards 1997.

${ }^{59}$ Franco and Sojo 1992, p. 28. Because, as Cheru and Gill (1997) point out, the distinction between the IMF and WB is blurry and because the US has a controlling interest within them, it is unlikely that highly contradictory policy prescriptions would emerge out of USAID - suggesting a certain neoliberal ideological convergence exists among these three key economic institutions. Of note, cross-conditionality was prohibited in 1984 in the Kemp-Kasten Act; nonetheless, a close relationship remained amongst these institutions (Honey 1994, p. 65).

${ }^{60}$ Drawn from Honey 1994; Judson 1993; Sojo 1991; Wilson 1999, p. 769. Mexico has also undertaken similar social compensation efforts through PRONASOL (see Soederberg 2001d).

${ }^{61}$ Honey 1994, p. 100.

${ }^{62}$ Wilson 1999, p. 769.

${ }^{63}$ Drawn from: Wilson 1999, p. 769.

64 Judson 1993, p. 154.

${ }^{65}$ Established in 1984 by USAID funding and the efforts of Costa Rican businessmen, PUSC and PLN politicians, and USAID officials, CINDE is a private-sector led investment and export promotion institution. The mandate of CINDE is to promote foreign investment, encourage domestic export-oriented production, and provide export-oriented business training.

${ }^{66}$ Honey 1994, p. 99.

${ }^{67}$ Honey 1994, p. 99.

${ }^{68}$ Honey 1994, p. 99.

${ }^{69}$ Honey 1994, p. 102; The participation of capitalist social forces have continued with, for example, Intel sponsoring computer labs and producing children's environmental books in conjunction with localities (e.g., San Antonio de Belén) that emphasize individualistic, versus social, responsibility. See "Salvemos nuestro Planeta" Intel. September 2001. In 1999, Intel had "Intel Education Programs" in 15 countries with 8 more in the US alone (Intel. 1999 Annual Report).

${ }^{70}$ Honey 1994, p. 102.

${ }^{71}$ Sojo 1991, pp. 50-1.

72 Sojo 1991, p. 51.

73 Sojo 1991, p. 52.

${ }^{74}$ Molina and Palmer 1997, p. 32; Bejarano 1992.

${ }^{75}$ Bejarano 1992, p. 207.

${ }^{76}$ Wilson 1998.

${ }^{77}$ Molina and Palmer 1997.; Bejarano 1992.

${ }^{78}$ Wilson 1998, p. 69.

${ }^{79}$ Molina and Palmer 1997, p. 31; Cruz and Facio 2000.

${ }^{80}$ The following analysis on peasants' resistance to globalization is taken from Edelman 1998, and 1999.

${ }^{81}$ Edelman 1998, and 1999.

${ }^{82}$ Goss and Pacheco 1999; Clark 1997; Honey 1994, p. 78.

${ }^{83}$ in Honey 1994, p. 79, 85; Lizano retired on 5 Nov 2002 and his successor, Paula Gutiérrez, has assured all that she will follow the same financial and credit policies as Lizano has historically (5 Nov 2002,

"Noticias." www.capitales.com).

${ }^{84}$ Clark 1997. 
${ }^{85}$ Clark 1997; Honey 1994, p. 66.

${ }^{86}$ The board was composed of seven businessmen tied to financial, industrial, and coffee capital, an economist, a political scientist, and an engineer/government technocrat; the majority had links to the ruling PLN government (Clark 1997).

${ }^{87}$ Brenes 1990, p. 74; Goss and Pacheco 1999; The deadline given by USAID for Costa Rica to comply, March 1983, was deemed unrealistic given the general economic crisis and they were therefore not held to it (Wilson 1998, p. 127).

${ }^{88}$ La Nación, Costa Rica's leading daily paper, ran an aggressive campaign during the early bank privatization period denouncing the "dogma of the nationalized banking system" (Honey 1994, p. 82).

${ }^{89}$ Honey 1994, p. 80-6; Booth 1998, Ch. 8.

${ }^{90}$ Valverde 1993; Goss and Pacheco 1999.

${ }^{91}$ Honey 1994, p. 88.

92 in Honey 1994, p. 88; cf. the principle of 'individual profits, socialised risks' (Patomäki 2001, Ch.4); Solís, a 2002 presidential candidate, was then Costa Rica's PLN Planning Minister.

${ }^{93}$ Robinson 2003, ch.1.

${ }^{94}$ Robinson 2003, p. 145.

${ }^{95}$ Panitch and Gindin 2003; Albo 2003. The geography of money literature offers much to be appreciated in this regard (see Corbridge, Thrift, and Martin 1994).

${ }^{96}$ For a critique of the tendency of the transnational historical materialists to reify ruling-class agency, see Colás 2002.

${ }^{97}$ Robinson 2003, 42-43, 47.

${ }^{98}$ By fictitious space I am referring to Robinson's transnationalism. My conceptual differences are captured lucidly by Albo who, referring to international capitalist competition, speaks of "local and particular forms of value production" that are connected with the "abstract and universal flows of money in the world market." (2003, 94).

99 Panitch and Gindin 2003, p.17.

${ }^{100}$ Langley 2002.

${ }^{101}$ Gowan 1999, pp. 24-5; cf. US structural power, Soederberg $2001 \mathrm{~b}$.

102 Judson 1993, p. 152. SAP-dependency has evolved into what Panitch and Gindin have referred to as a 'new imperial bond', or foreign direct investment dependency (2003, p.19).

${ }^{103}$ The following is drawn from Fox 1998, and 2003.

${ }^{104}$ From 1945 to 1995 , Costa Rica received \$2.9 billion of 1994 dollars in aid - only Israel, Vietnam, Egypt, and Jamaica have received more per capita (Fox 1998).

${ }^{105}$ The following numbers are drawn from: IMF 2002 and ECLAC 2003.

${ }^{106}$ Godfrey, Mike 2004, “Costa Rican Markets Stabilize Following Run on Dollar Funds,” Tax-News.com, Washington, 17 May 2004.

${ }^{107}$ Rodrik's comments taken from: "Doubts inside the Barricades." The Economist. 26 Sept 2002.

${ }^{108}$ Stiglitz, Joseph. "The Disastrous Effects of Instability.” Financial Times. 22 Sept 2002.

${ }^{109}$ For a critical review of collective action clauses, see Soederberg (forthcoming).

110 Pauly 1997.

111 "No Rigs Allowed." On Earth: Environmental Politics People 24 (2002); Cajiao 2001.

112 Booth 1998, p. 165.

${ }^{113}$ Wilson 1998, p. 155; Booth 1998, p. 165.

114 'Rodríguez Changes His Focus,' 15 October 1999, http://www.ticotimes.net/archive/10_15_99_3.htm

${ }^{115}$ Booth 1998, p. 165; Wilson 1999, p. 770. Of interest, a similar month long national teacher's strike recently occurred in Honduras (June-July 2004). The teachers won the majority of their demands, celebrating their victory even while new IMF president Rodrigo Rato was holding meeting in Honduras.

${ }^{116}$ La Nación. "Paro en Servicio de AyA." 3 October 2001

117 "Noticias." www.capitals.com. 1 November 2002.

${ }^{118}$ Drawn from DFAIT news release: http://www.dfait-maeci.gc/tna-nac/CR-high-e.asp

119 "Noticias." www.capitales.com. 31 October 2002.

120 "Noticias." www.capitales.com . 5 November 2002

121 "Noticias." www. capitales.com. 7 November 2002

${ }^{122}$ The following is taken from: Mora, José Eduardo, “Activists Pledge to Keep Up Fight Against U.S. Trade Deal,” http://insidecostarica.com, 30 January 2004. 
${ }^{123}$ in the documentary film, "The Revolution will not be Televised," Power Pictures 2002 Production.

${ }^{124}$ For a discussion of finance and everyday life, see Langley 2003.

${ }^{125}$ Stuart Hall (1983), in Feigenbaum and Henig 1994, p. 200.

${ }^{126}$ Pauly 1997.

${ }^{127}$ Wood 2003, p. 126.

${ }^{128}$ Wood 2003, p. 134.

${ }^{129}$ Wood 2003, p. 139-40.

${ }^{130}$ Panitch 1994; Panitch and Gindin 2003; Albo 2003.

${ }^{131}$ Brenner 1998. 